\title{
Tomato Yellow Leaf Curl Virus-Is Causes a Novel Disease of Common Bean and Severe Epidemics in Tomato in Spain
}

\author{
Jesús Navas-Castillo, Sonia Sánchez-Campos, and Juan Antonio Díaz, Estación Experimental "La Mayora," \\ Consejo Superior de Investigaciones Científicas, 29750 Algarrobo-Costa, Málaga, Spain; Elisa Sáez-Alonso, De- \\ partamento de Sanidad Vegetal, Consejería de Agricultura y Pesca, Almería, Spain; and Enrique Moriones, \\ Estación Experimental "La Mayora," Consejo Superior de Investigaciones Científicas, 29750 Algarrobo-Costa, \\ Málaga, Spain
}

\begin{abstract}
Navas-Castillo, J., Sánchez-Campos, S., Díaz, J. A., Sáez-Alonso, E., and Moriones, E. 1999. Tomato yellow leaf curl virus-Is causes a novel disease of common bean and severe epidemics in tomato in Spain. Plant Dis. 83:29-32.

Field surveys were conducted in the autumn of 1997 in the main tomato (Lycopersicon esculentum)-growing regions of southern Spain following a severe tomato yellow leaf curl epidemic in tomato. Tomato yellow leaf curl virus (TYLCV)-Is was found to have spread to all regions and to coexist with TYLCV-Sr, which has been present since 1992. TYLCV-Is was also shown to be the causal agent of bean leaf crumple, a novel disease that has caused severe economic losses in fresh-market common bean (Phaseolus vulgaris) crops of southern Spain since September 1997. The disease was reproduced by infecting beans with cloned TYLCV-Is obtained from infected tomato plants collected in Almería. This is the first report of bean leaf crumple disease and the first report of a geminivirus in bean from Spain.
\end{abstract}

Additional keywords: geminivirus, Lycopersicon esculentum, Phaseolus vulgaris, TYLCV

Tomato yellow leaf curl disease (TYLC) causes devastating annual damage in tomato (Lycopersicon esculentum) crops of many tropical, subtropical, and temperate regions of the world (9). The disease is caused by several whitefly (Bemisia tab$a c i$ )-transmitted geminiviruses, all of which are referred to as tomato yellow leaf curl virus (TYLCV). TYLCV isolates reported so far have been grouped in several species in the "subgroup III Geminivirus" (proposed to be named Begomovirus) genus of the family Geminiviridae (4). All, except for a TYLCV from Thailand (27), have a monopartite genome. Monopartite TYLCVs have a similar genome organization consisting of two virion sense (precoat, $V 1$; and coat, $V 2$ ) and four complementary sense $(C 1, C 2, C 3$, and $C 4)$ genes separated by a short intergenic region (IR; $2,8,12,19,21)$.

TYLC has threatened tomato crops of southern Spain since 1992 (17). Two iso-

Corresponding author: E. Moriones

E-mail: moriones@eelm.csic.es

This work was financed by project AGF96-0421 of the Comisión Interministerial de Ciencia y Tecnología (Spain), and by Caja Rural de Málaga, Spain. S. Sánchez-Campos is the recipient of a predoctoral fellowship from the Ministerio de Educación y Cultura, Spain.

Accepted for publication 16 September 1998.

Publication no. D-1998-1029-01R

(C) 1999 The American Phytopathological Society lates of TYLCV from the first epidemic outbreak, named TYLCV-M and TYLCVAlm, have been cloned and sequenced $(21,26)$. These isolates are almost identical (99\% nucleotide sequence identity) and belong to the TYLCV-Sr species of the Begomovirus genus. In June 1997, a severe outbreak of TYLC disease was reported in tomato crops of Almería. This outbreak was associated with infections caused by isolates of the TYLCV-Is species (18) which had not been previously reported in Spain. In this paper we report the widespread occurrence of TYLCV-Is in the main tomato-growing regions of southern Spain and evidence for its involvement in a novel disease of fresh-market bean (Phaseolus vulgaris). This is the first report of a geminivirus infection in common bean from Spain.

\section{MATERIALS AND METHODS}

Virus sources. Tomato (L. esculentum cv. Daniela) plants exhibiting an abnormally strong upward curling of leaflet margins (Fig. 1A) relative to symptoms normally observed in TYLC-affected plants in Spain (17; Fig. 1B) were collected in June 1997 from a plastic house in Almería (region III, Fig. 2). Following previously reported analyses (18), sample SP72/97 was demonstrated to be infected only by TYLCV-Is and was selected for further characterization.

Construction of an infectious clone of SP72/97-TYLCV-Is. A putative fulllength fragment of SP72/97-TYLCV-Is was detected, excised, and extracted from low-melting-temperature agarose gels after electrophoresis of total nucleic acids from sample SP72/97 digested with BamHI. An aliquot was cloned into pBluescript $\mathrm{SK}+$ (Stratagene, La Jolla, CA) and a clone (pSP72/97) containing a potentially fulllength insert was selected for further analysis. A 1.7-mer clone of the insert of pSP72/97 was constructed by adding the full-length fragment into the unique BamHI site of a 0.7-mer clone previously obtained by a SmaI-SphI deletion in pSP72/97. The 1.7-mer fragment was subcloned into the binary vector pBin19 (3). The recombinant clone (p1.7SP72/97) has proved to be infectious, and transmission of progeny virus by Bemisia tabaci has been demonstrated on tomato (unpublished). DNA manipulation and cloning were carried out following standard methods (29) or methods described by Noris et al. (21). For hybridization, a digoxigeninlabeled DNA probe covering the IR was prepared from the clone pPORT2 of an isolate of TYLCV-Is from Portugal (14). The probe was prepared by polymerase chain reaction (PCR) with primers MA-30 (5'-GAGCACTTAGGATATGTGAGG-3', nucleotides 2,566 to 2,586) and MA-31 (5'-AGTGGATCCCACATATTGC-3', nucleotides 170 to 152 ) based on the sequence of the clone pPORT2 (unpublished).

Etiology of a novel disease of common bean. Unusual virus-like disease symptoms were observed in September 1997 in plastic house-grown (Almería, region III, Fig. 2) and field-grown (Málaga, region I, Fig. 2) staked fresh market bean (P. vulgaris cv. Donna and Garrafal Oro, respectively) heavily infested with $B$. tabaci. Samples from 40 symptomatic and 15 asymptomatic plants were collected and analyzed for the presence of viruses reported in common bean in Spain, including potyviruses, cucumber mosaic cucumovirus (CMV), and tomato spotted wilt tospovirus (TSWV; 5,6; E. Sáez-Alonso, unpublished). Analyses were done by direct double-antibody sandwich enzymelinked-immunosorbent assay (DAS-ELISA; 7). Antibodies were against a broad-spectrum of potyviruses (anti-Potyvirus group; Agdia, Inc., Elkhart, IN), CMV, or TSWV (Loewe Biochemica GmbH, Otterfing, 

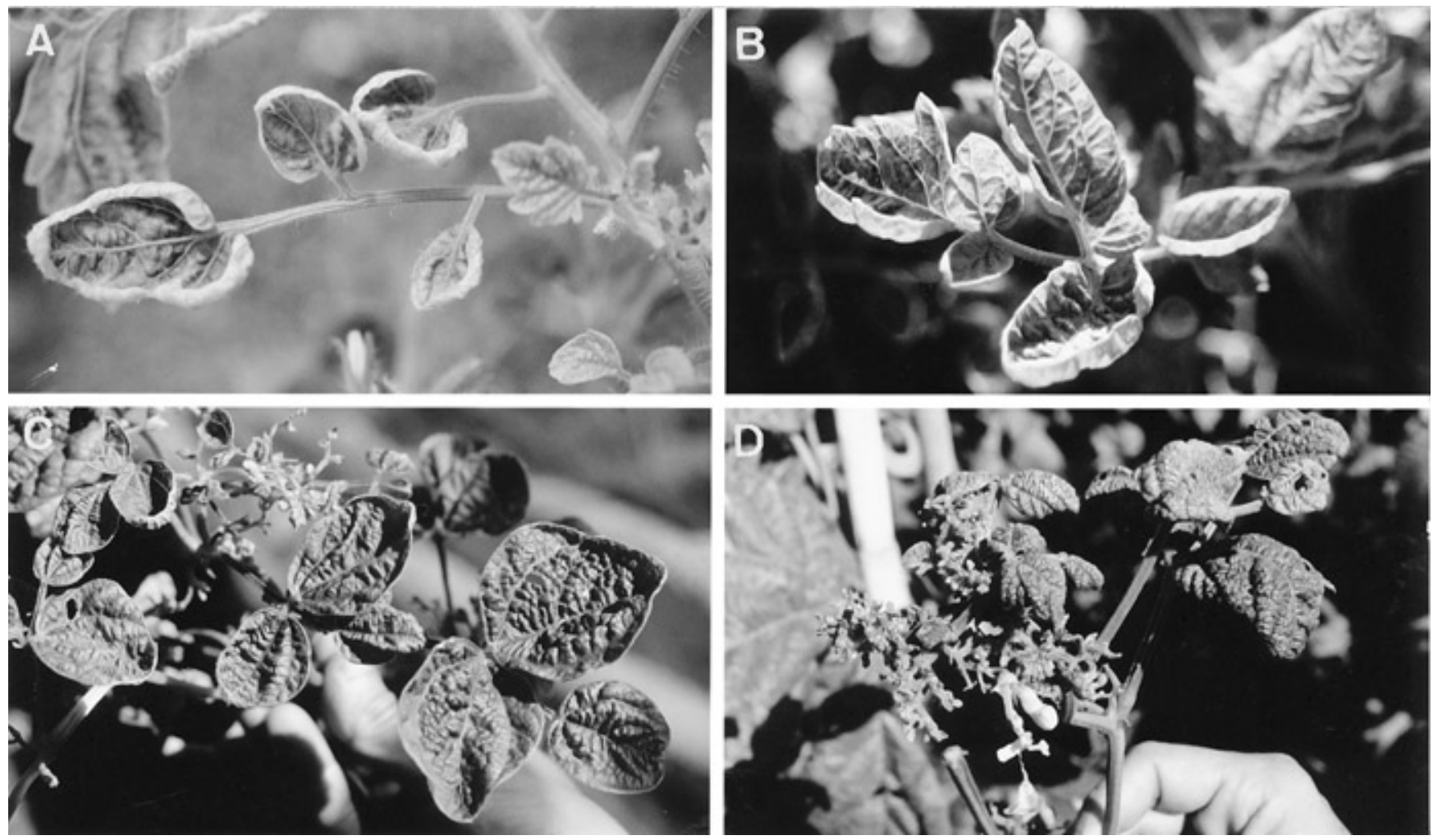

Fig. 1. Symptoms of tomato yellow leaf curl virus (TYLCV) infection in Spain. (A) Severe and (B) normal upward curling of leaflet margins in tomato (Lycopersicon esculentum) caused by TYLCV-Is and TYLCV-Sr species, respectively; and (C) leaf crumple, thickening, and upward curling and (D) abnormal apical shoot proliferation in common bean (Phaseolus vulgaris) caused by TYLCV-Is.

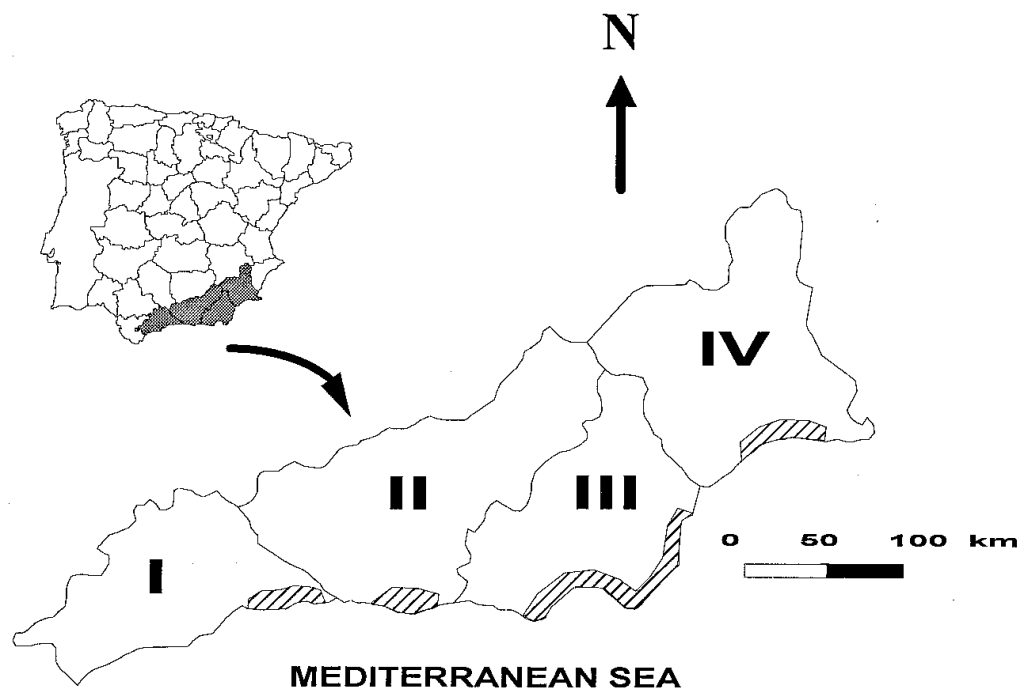

Fig. 2. Location of regions I to IV where field surveys for occurrence of tomato yellow leaf curl virus-Is in fresh market tomato (Lycopersicon esculentum) were made during autumn 1997. The main production areas are shadowed.

Germany), and were used as recommended by the suppliers. The same samples were also analyzed by hybridization of petiole cross-sections printed on nylon ${ }^{+}$membranes (Boehringer Mannheim, Mannheim, Germany; hereafter referred to as tissue blotting) with probes specific to TYLCV$\mathrm{Sr}$ and TYLCV-Is. As the IR is the least conserved region among geminivirus genomes (1), probes specific to TYLCV-Sr and -Is were prepared by PCR to IR of
TYLCV-Sr isolate $\mathrm{M}$ and TYLCV-Is isolate SP72/97, respectively. PCR amplification reactions were performed with the primer pair MA-14/MA-15 (MA-14: 5'TGCATTTATTTGAAAACG-3', nucleotides 2,587 to 2,604; MA-15: 5'-AAAGGATCCCACATATTG-3', nucleotides 162 to 145), based on the sequence of TYLCVM (21) for TYLCV-Sr and MA-30/MA-31 for TYLCV-Is. Total nucleic acids were also extracted from the collected samples and specific fragments of the $V 1$ and $C 2$ genes were amplified as reported (18) for single-strand conformation polymorphism (SSCP) analysis (13) and direct sequencing. Cultures of Agrobacterium tumefaciens strain LBA4404 transformed with the recombinant plasmid p1.7SP72/97 (11) were used to inoculate (hereafter referred to as agroinoculation) bean ( $P$. vulgaris $\mathrm{cv}$. Donna) plants at the first trifoliate leaf growth stage. After 20 days, the 36 plants inoculated were analyzed for TYLCV infection by tissue blotting, and young tissues were extracted for SSCP analyses of both pre-coat $(V 1)$ and $C 2$ fragments. Symptoms were recorded 30 days after inoculation.

Field surveys. A survey was undertaken during autumn 1997 in the main tomatogrowing regions of southern Spain, covering a transect of about $500 \mathrm{~km}$ along the Mediterranean coast (regions I to IV, Fig. 2) to determine the occurrence of TYLCVIs. Samples from TYLC-affected tomato plants were collected from fields and plastic houses. Also, to ascertain if the unusually severe TYLC symptoms observed in tomato crops were associated to infections caused by TYLCV-Is, several tomato samples exhibiting the severe (Fig. 1A) or normal (Fig. 1B) TYLC symptoms were collected from a plastic-house crop grown in Almería (region III, Fig. 2) where plants with both kind of symptoms coexisted. Samples were analyzed by tissue blotting with probes specific to TYLCV-Sr or TYLCV-Is as described above. 

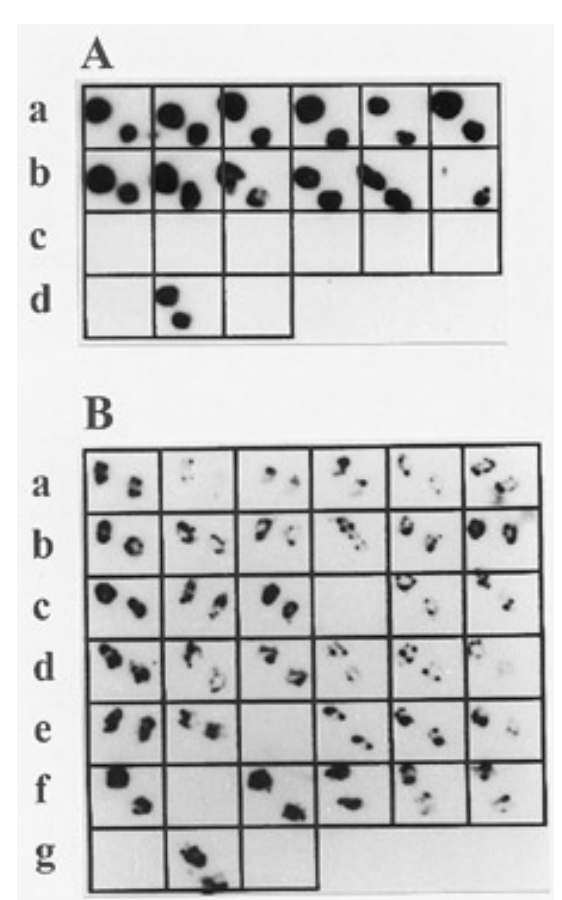

Fig. 3. Results of analysis of common bean (Phaseolus vulgaris) plants collected from crops affected by the bean leaf crumple disease or agroinoculated with an infectious clone obtained for the SP72/97-tomato yellow leaf curl virus (TYLCV)-Is isolate collected during the first epidemic outbreak of this geminivirus species in Spain. (A) Petiole cross section prints from 12 symptomatic plants collected from plastic-house (row a)- or field (row b)grown crops. Row c contains prints from asymptomatic plants collected in the same survey. (B) Petiole cross-section prints from 36 agroinoculated plants (rows a to $\mathrm{f}$ ). Controls in row $\mathrm{d}$ (A) and $\mathrm{g}$ (B) are healthy, SP72/97-TYLCVIs- or M-TYLCV-Sr-infected tomato (Lycopersicon esculentum) plants, respectively. Two prints per tested plant were made. Prints were hybridized with probes specific to TYLCV-Is.

\section{RESULTS}

Etiology of a novel disease of common bean. A novel virus-like disease was observed in field- (Málaga, region I, Fig. 2) and plastic-house-grown (Almería, region III, Fig. 2) staked fresh market bean crops in autumn 1997. Incidences of symptomatic plants was up to $80 \%$ in some fields. Symptoms consisted of thickening, epinasty, crumpling, and blade reduction of leaves; upward curling of leaves was also observed at times (Fig. 1C). A characteristic abnormal shoot proliferation and internode reduction occurred in apical parts of affected plants; the very small leaves formed resulted in a bushy appearance (Fig. 1D). Symptoms were noticed especially in new shoots emerging from the basal part of the plants. When infected early, plants showed dramatic stunting and abortion of new inflorescences, and production was entirely lost. This disease, named bean leaf crumple, was observed in crops heavily infested with B. tabaci. A

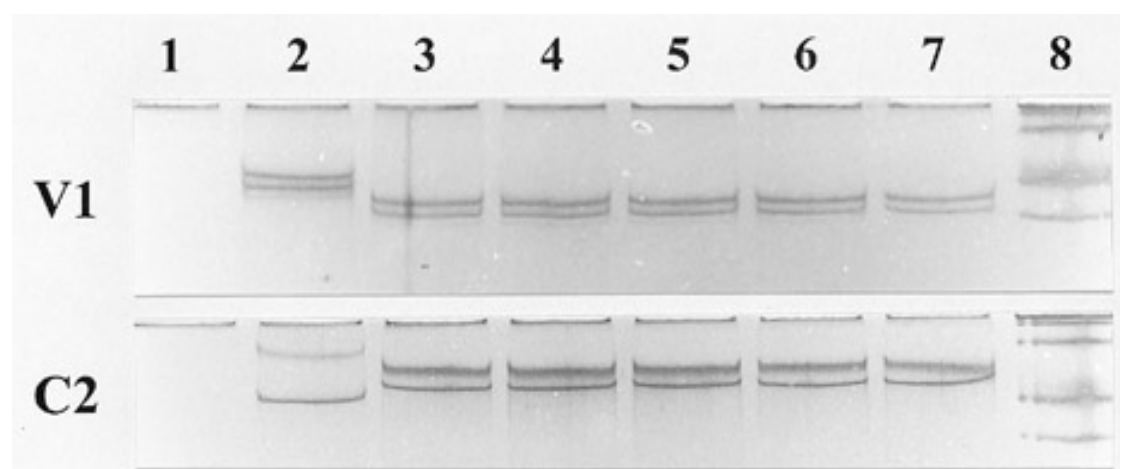

Fig. 4. Single-strand conformation polymorphism patterns of the pre-coat $(V 1)$ and $C 2$ polymerase chain reaction fragments amplified from a SP72/97-tomato yellow leaf curl virus (TYLCV)-Is agroinfected bean (Phaseolus vulgaris) plant and from a field bean plant affected by the bean leaf crumple disease (lanes 5 and 7, respectively). Patterns from SP72/97-TYLCV-Is agroinfected and Bemisia tabaci-mediated-infected tomato (Lycopersicon esculentum) plants are shown in lanes 4 and 6, respectively. Controls are from healthy and M-TYLCV-Sr- or SP72/97-TYLCV-Is field-infected tomato plants (lanes 1,2, and 3, respectively). The 1 kilobase-ladder DNA molecular marker is included in lanes 8 . Electrophoresis was performed in $12 \%$ non-denaturing polyacrylamide gels ( 110 by 125 by 1 $\mathrm{mm})$ at $200 \mathrm{~V}$ for $5 \mathrm{~h}$ at $4^{\circ} \mathrm{C}$, and gels were stained with silver nitrate.

possible implication of TYLCV in bean leaf crumple disease was suspected, because TYLC-affected tomato crops were present nearby. Analysis of the bean samples showed that none of the symptomatic plants reacted in ELISA for potyviruses, CMV, or TSWV. Tissue-blotting assays for TYLCV-Sr were negative (results not shown), whereas a clear hybridization signal was obtained with probes for TYLCVIs (Fig. 3A). None of the samples collected from the asymptomatic plants reacted in ELISA or tissue blotting. SSCP patterns for $V 1$ and $C 2$ fragments amplified from positive-reacting samples were identical to those of SP72/97-TYLCV-Is (Fig. 4). The $V 1$ and $C 2$ amplified fragments were directly sequenced for one of the samples, and a $100 \%$ nucleotide sequence identity with the sequence of the corresponding fragments of SP72/97-TYLCV-Is was found. To ascertain if TYLCV-Is was the etiological agent for the bean leaf crumple syndrome, healthy bean plants were agroinoculated with the infectious clone of SP72/97-TYLCV-Is previously obtained. Of 36 inoculated plants, 33 were infected systemically by TYLCV-Is (Fig. 3B) and developed symptoms similar to those observed in the field-infected beans. SSCP patterns for $V 1$ and $C 2$ fragments amplified from these plants were identical to those of SP72/97-TYLCV-Is (Fig. 4).

Occurrence of TYLCV-Is. TYLCV-Is was found widely dispersed throughout the main tomato-growing regions of southern Spain by autumn 1997. Analysis of TYLCsymptomatic tomato samples collected from Málaga, Granada, Almería, or Murcia provinces (regions I to IV, respectively; Fig. 2) showed that TYLCV-Is occurred frequently in all regions either alone or as mixed infections with TYLCV-Sr (Table 1). A close relationship was found between symptoms exhibited in tomato plants and the TYLCV species present. A total of 19 tomato plants from a plastic-house crop grown in Almería (where plants with different symptoms were present) were analyzed. Results consistently associated the TYLCV-Is infection with the unusually severe TYLC symptoms. All 10 plants with severe symptoms analyzed were found to be infected by TYLCV-Is, either alone or together with TYLCV-Sr; whereas, with one exception (a plant with a mixed infection of TYLCV-Is and -Sr), the 9 plants showing normal symptoms were infected only by TYLCV-Sr.

\section{DISCUSSION}

Two important results described in this paper demonstrate the widespread occurrence of TYLCV-Is in southern Spain and its association with a new disease in common bean. The presence of TYLCV-Is in Spain is of concern because it is consistently associated with more severe effects in tomato than the previously existing TYLCV-Sr species. Presence of TYLCV-Is may require changes in breeding programs for virus resistance in Spain (22) because differences in the behavior of breeding lines against different TYLCVs have been reported (10). The simultaneous occurrence of both species within a single crop and even in a single plant is important because recombinants might arise with unpredictable consequences on pathogenicity. Such recombination has been suggested as a powerful factor in the evolution of whitefly-transmitted geminiviruses, not only in the long term but also in the immediate future (28). Natural genetic recombination between geminiviruses regarded as separate species has been demonstrated for cassava mosaic geminiviruses, and caused a severe form of cassava mosaic disease in Uganda which has devastated crops since 1988 (30).

In addition to being a severe pathogen of tomato, TYLCV-Is is the causal agent of the novel bean leaf crumple disease that has recently threatened common bean 
Table 1. Occurrence of tomato yellow leaf curl virus (TYLCV)-Is in fresh-market tomato (Lycopersicon esculentum) crops in the main tomato growing regions of southern Spain during autumn 1997

\begin{tabular}{lccccc}
\hline & & & \multicolumn{3}{c}{ No. samples infected by TYLCV } \\
\cline { 3 - 6 } Region & No. fields surveyed & No. samples tested & Is & Is + Sr & Sr \\
\hline I. Málaga & 12 & 130 & 80 & 36 & 9 \\
II. Granada & 4 & 21 & 9 & 21 & 3 \\
III. Almería & 13 & 94 & 16 & 9 & 57 \\
IV. Murcia & 2 & 24 & 0 & 15 \\
\hline
\end{tabular}

${ }^{a}$ Petiole cross-sections of samples collected were printed on nylon ${ }^{+}$membranes and hybridized with probes specific to TYLCV-Sr and TYLCV-Is.

crops in Spain. This is the first reported geminivirus in bean crops from Spain. There is a report of TYLCV naturally infecting beans in Israel (20); however, no information on symptoms or characterization of the virus involved were presented.

In recent years, TYLCV-Is has been reported to cause epidemics in countries from both eastern and western hemispheres $(9,14-16,24,25)$. The origin and spread pathways of this virus, especially between distant countries, is a matter of discussion. It is possible that TYLCV-Is was spread by movement of infected plant material or by plants harboring viruliferous whiteflies between distant countries. TYLCV-Is is the only known geminivirus introduced from the eastern to the western hemisphere (23). It appears that TYLCV-Is was unknowingly introduced via infected tomato transplants to the Dominican Republic $(23,24)$ and then expanded to other Caribbean countries $(15,16,25)$. A similar situation may have occurred in the western Mediterranean basin, where TYLCV-Is was first reported in Portugal in 1995 (14) and a year later in Spain (18).

The present report of TYLCV-Is infecting bean in Spain is important not only because of the economic importance of this crop but because bean is often used as an intercrop between tomato crops. Furthermore, beans are grown as an alternative to tomatoes in areas severely affected by TYLCV epidemics. Therefore, maintenance of high TYLCV infection levels is ensured year-round alternately in tomato and bean crops, and reduces the possibilities for managing TYLCV epidemics. In the absence of effective control methods against TYLCV infections, consequences for the local growers' economy can be dramatic. The need for efforts to develop TYLCV-resistant cultivars has clearly increased.

\section{ACKNOWLEDGMENTS}

We thank G. P. Accotto for providing us with the pPORT2 full-length clone of an isolate of the TYLCV-Is reported in Portugal, and G. P. Accotto and S. M. Garnsey for critical review of the manuscript.

\section{LITERATURE CITED}

1. Abouzid, A. M., Polston, J. E., and Hiebert, E. 1992. The nucleotide sequence of tomato mottle virus, a new geminivirus isolated from tomatoes in Florida. J. Gen. Virol. 73:3225-3229.

2. Antignus, Y., and Cohen, S. 1994. Complete nucleotide sequence of an infectious clone of a mild isolate of tomato yellow leaf curl virus (TYLCV). Phytopathology 84:707-712.

3. Bevan, M. 1984. Binary vectors for plant transformation. Nucleic Acids Res. 12:87118721.

4. Briddon, R. W., and Markham, P. G. 1995. Family Geminiviridae. Pages 158-165 in: Virus Taxonomy: Classification and Nomenclature of Viruses. Sixth Rep. Int. Comm. Taxon. Viruses. F. A. Murphy, C. M. Fauquet, D. H. L. Bishop, S. A. Ghabrial, A. W. Jarvis, G. P. Martelli, M. A. Mayo, and M. D. Summers, eds. Springer-Verlag, New York.

5. Castro, S., de Blas, C., Sáiz, M., Carazo, G., Fresno, J., and Romero, J. 1992. Virus y micoplasmas que afectan a judías, garbanzos y yeros en España. Pages 181-184 in: I Jornadas Técnicas sobre Leguminosas de Grano. Universidad de Valladolid and Junta de Castilla y León, Palencia.

6. Castro, S., Sáiz, M., Carazo, G., de Blas, C., and Romero, J. 1991. Incidencia de virus en judías ( Phaseolus vulgaris L.) españolas. Actas de Horticultura 8:189-192.

7. Clark, M. F., and Adams, A. N. 1977. Characteristics of the microplate method of enzyme-linked immunosorbent assay for the detection of plant viruses. J. Gen. Virol. 34:475-483.

8. Crespi, S., Noris, E., Vaira, A. M., and Accotto, G. P. 1995. Molecular characterization of cloned DNA from a tomato yellow leaf curl virus isolate from Sicily. Phytopathol. Mediterr. 34:93-99.

9. Czosnek, H., and Laterrot, H. 1997. A worldwide survey of tomato yellow leaf curl viruses. Arch. Virol. 142:1391-1406.

10. Fargette, D., Leslie, M., and Harrison, B. D. 1996. Serological studies on the accumulation and localisation of three tomato leaf curl geminiviruses in resistant and susceptible $L y$ copersicon species and tomato cultivars. Ann. Appl. Biol. 128:317-328.

11. Höfgen, R., and Willmitzer, L. 1988. Storage of competent cells for Agrobacterium transformation. Nucleic Acids Res. 16:9877.

12. Kheyr-Pour, A., Bendahmane, M., Matzeit, N., Accotto, G. P., Crespi, S., and Gronenborn, B. 1991. Tomato yellow leaf curl virus from Sardinia is a whitefly-transmitted monopartite geminivirus. Nucleic Acids Res. 19:6763-6769.

13. Koenig, R., Lüdecke, P., and Haeberle, A. M. 1995. Detection of beet necrotic yellow vein virus strains, variants and mixed infections by examining single-strand conformation polymorphisms of immunocapture RT-PCR products. J. Gen. Virol. 76:2051-2055

14. Louro, D., Noris, E., Veratti, F., and Accotto, G. P. 1996. First report of tomato yellow leaf curl virus in Portugal. Plant Dis. 80:1079.

15. Martínez-Zubiaur, Y., Zabalgogeazcoa, I., De Blas, C., Sánchez, F., Peralta, E. L., Romero, J., and Ponz, F. 1996. Geminiviruses associated with diseased tomatoes in Cuba. J. Phytopathol. 144:277-279.

16. McGlashan, D., Polston, J. E., and Bois, D.
1994. Tomato yellow leaf curl geminivirus in Jamaica. Plant Dis. 78:1219.

17. Moriones, E., Arnó, J., Accotto, G. P., Noris, E., and Cavallarin, L. 1993. First report of tomato yellow leaf curl virus in Spain. Plant Dis. 77:953.

18. Navas-Castillo, J., Sánchez-Campos, S., Díaz, J. A., Sáez-Alonso, E., and Moriones, E. 1997. First report of tomato yellow leaf curl virus-Is in Spain: coexistence of two different geminiviruses in the same epidemic outbreak. Plant Dis. 81:1461.

19. Navot, N., Pichersky, E., Zeidan, M., Zamir, D. and Czosnek, H. 1991. Tomato yellow leaf curl virus: a whitefly-transmitted geminivirus with a single genomic component. Virology 185:151161.

20. Navot, N., Zeidan, M., Pichersky, E., Zamir, D., and Czosnek, H. 1992. Use of the polymerase chain reaction to amplify tomato yellow leaf curl virus DNA from infected plants and viruliferous whiteflies. Phytopathology 82:1199-1202

21. Noris, E., Hidalgo, E., Accotto, G. P., and Moriones, E. 1994. High similarity among the tomato yellow leaf curl virus isolates from the West Mediterranean Basin: the nucleotide sequence of an infectious clone from Spain. Arch. Virol. 135:165-170.

22. Picó, B., Díez, M. J., and Nuez, F. 1997. Response of tomato cultivars partially resistant to TYLCV in Spain. Tomato Genet. Coop. Rep. 47:25-26.

23. Polston, J. E., and Anderson, P. K. 1997. The emergence of whitefly-transmitted geminiviruses in tomato in the Western Hemisphere. Plant Dis. 81:1358-1369.

24. Polston, J. E., Bois, D., Serra, C. A., and Concepción, S. 1994. First report of tomato yellow leaf curl-like geminivirus from tomato in the Western Hemisphere. Plant Dis. 78:831.

25. Ramos, P. L., Guerra, O., Dorestes, V., Ramirez, N., Rivera-Bustamante, R., and Oramas, P. 1996. Detection of TYLCV in Cuba. Plant Dis. 81:1095.

26. Reina, J., Jiménez, J., Bejarano, E. R., Guerra, J. M., Cuadrado, I. M., and García, C. 1994. El virus del rizado amarillo del tomate (TYLCV). Hortofruticultura V (6):36-40.

27. Rochester, D. E., de Paulo, J. J., Fauquet, C. M., and Beachy, R. N. 1994. Complete nucleotide sequence of the geminivirus tomato yellow leaf curl virus, Thailand isolate. J. Gen. Virol. 75:477-485.

28. Rybicki, E. P. 1994. A phylogenetic and evolutionary justification for three genera of Geminiviridae. Arch. Virol. 139:49-77.

29. Sambrook, J., Fritsch, E. F., and Maniatis, T. A. 1989. Molecular cloning: A laboratory manual. 2nd ed. Cold Spring Harbor Laboratory, Cold Spring Harbor, NY.

30. Zhou, X., Liu, Y., Calvert, L., Munoz, C., OtimNape, G. W., Robinson, D. J., and Harrison, B. D. 1997. Evidence that DNA-A of a geminivirus associated with severe cassava mosaic disease in Uganda has arisen by interspecific recombination. J. Gen. Virol. 78:2101-2111. 